\title{
Vocational High School Quality Viewed from Teacher Competencies
}

\author{
Yatwawan Lolo ${ }^{1}$, Putu Sudira ${ }^{2}$ \\ ${ }^{1}$ Technology and Vocational Education, Graduate of Yogyakarta State University \\ Email: yatwawanlolo@gmail.com \\ ${ }^{2}$ Postgraduate of Yogyakarta State University \\ Email: putupanji@uny.ac.id
}

(Received: July-2018; Reviewed: July-2018; Accepted: August-2018; Published: August-2018)

(C)2018 -EST Graduate Program Universitas Negeri Makassar. This is an article with open access under license CC BY-NC-4.0 (https://creativecommons.org/licenses/by-nc/4.0/).

\begin{abstract}
This study aims to describe the competence of productive teachers of Vocational High School in North Morowali Regency in terms of four teacher competencies. This research is a descriptive study, conducted in four accredited Vocational High Schools in North Morowali District. The respondents were 178 students. Data were collected through documentation and questionnaires. Data were analyzed descriptively by display in the form of data categories and graphs. The results showed: (1) pedagogic competence of teacher equal to $66,76 \%$ with high category, professional competence of teacher equal to 77,92\% including high category, teacher personality competence equal to $78,66 \%$ including high category, teacher social competence equal to $79,82 \%$ including high category.
\end{abstract}

Keywords: teacher, vocational, competence

\section{INTRODUCTION}

Graduates of vocational education in central Sulawesi today, have not met expectations according to educational goals. Data at BPS (2017) indicates that there are still many graduates of Vocational High School that have not been absorbed well in the world of work that is equal to $5.12 \%$. Vocational education is responsible for preparing learners so they can work according to their skills. This is in accordance with the strategic three (3) Directorate of Vocational Education 2015-2019 namely the increasing quality of services and graduates of vocational secondary education. Supported by Government Regulation No. 66 of 2010 on Management and Implementation of Education which states that vocational education has the task to prepare learners in order to have the ability to enter the world of work, that is fill the available job opportunities, or work independently. Vocational High School is one part in the preparation of human resources to be able to work in a particular field of competence.

Vocational School Vocational High School (VHS) vocational competencies are needed in order to develop and demonstrate educational behavior. (MacKenzie, 2009; Noe, 2001) states that competence is an individual's ability to perform a task or role, integrating the knowledge, skills, and personal characteristics required to meet specific demands or special job requirements. A vocational teacher should have capability, capacity and performance in managing the teaching and learning program, so that learners have a good learning experience in the control of work competence. As Tilak (2002) points out in The Handbook On 
Educational Research In The Asia Pacific Region that: General or vocational education? This is a "tough choice" in many developing countries. In the human capital framework, general education creates 'general human capital' and vocational and technical education 'specific human capital' Vocational education has a advantage, imbibing specific job relevant skill, that can make the worker more readily suitable for a given job and would make $\mathrm{him} / \mathrm{her}$ thus more productive. Then vocational education according to Prosser and Quigley (1950) in Dharma, Sugiyono, Mulyatiningsih, Sutopo, Irwanto, Palunsu, Triatmojo, Siswanto (2013) states that: Vocational education is essentially a matter of estabilishing certain habits through repetitive training both in thinking and in doing, it is primarily concerned with what these habits shall be and how they shall be taught. When consider the matter a litle further we find there are general group of habbits requires 1 . Habits giving adaption to working enviroment 2. Process habits 3 . Thinking habits.

Mupinga and Livesay (2004) state that the definition of vocational education is: Organized educational programs offering a sequence of courses directly related to preparing individuals for paid or unpaid employement in current or emerging occupation requiring other than a baccalaureate or advanced degree. Program include competency based applied learning, which contributes to an individuals academic knowledge, higher order reasoning, problem solving skill, and the occupational-specific skills necessary for economic independence as a productive and contributing member of society.

The program includes competency-based learning, which contributes to individual academic knowledge, high-level reasoning, problem-solving skills, and special skills for jobs that require economic independence as productive and contributing members of society. Some of the opinions of the experts above can be illustrated that vocational education is an option that takes to be able to get special skills to get jobs that can bring economic benefits because through vocational education learners are taught to think high level in solving problems faced in the changing world of work is increasingly fast. Vocational education will develop if the VHS Teachers have competence that qualified in the implementation of the process of learning theory and practice. Implementation of VHS teachers' competence can be seen when they perform their duties as teachers and educators. Implementation of learning is closely related to the performance of teachers in carrying out educational tasks and also train students in theory and practice. Competence affects job responsibilities and the performance of each individual in the work and is usually divided into two categories, namely technical and behavioral. It is further said that the key aspects of the definition of competence are: (a) every job / work can be effectively and adequately explained in terms of the task successfully performed by the worker in a particular job; (b) all Tasks have direct implications for Awareness, Knowledge, Skills, and Competency Attitudes that trainees must have in order to perform with the right task; (c) an assessment is made of how individuals actually do work; (d) an incompetent individual so long as he / she can not apply his knowledge and skills appropriately in the workplace no matter how much knowledge he or she possesses; (e) the assessment must be objective by doing so against the defined competency standard (Level).

In general, VHS teachers must have four competencies in performing their duties as teachers, educators and trainers. The four competencies are described as follows:

Personality Competence. Law no. Law No. 14 Year 2005 on Teachers and Lecturers Article 10 paragraph 1, explained that the meaning of pedagogic competence is the ability to manage learning that includes understanding of learners, design and implementation of learning, evaluation of learning, and development of learners to actualize various potentials. Efforts to deepen the understanding of these learners are realized that their talents of interest and level of ability vary so that individual services are also different. Although the teaching materials presented in the class are similarly classed, the students' individual understanding is different. Therefore, teachers are expected to guide learners whose learning acceleration is backward so that at the end of learning will have equality. Firdausi and Barnawi (2012: 27) said that: The learning process involves the ability of teachers to help develop all the potential possessed by learners.

Personality competence is the ability of a solid personality, noble character, wise, and authoritative and a role model of learners. Vocational teachers as educators whose main task is to teach, has personality characteristics 
that affect the success of human resource development. Firdausi and Barnawi (2012: 32) say this personality competence as personal competence. Personal competence is the personal ability of a vocational school teacher needed to be a good teacher. This personal competence includes personal abilities related to self-understanding, self-acceptance, selfdirection, and self-realization. In line with that Suyanto and Jihad (2013: 16) say "the personality of a teacher has a direct and cumulative effect on student life and habits of learning". Students will absorb attitudes, reflect feelings, absorb beliefs, imitate behavior and quote the teacher's statements. Personality competence is a personal ability that reflects a steady, stable, mature, wise, and authoritative personality, a role model for learners, and noble character.

Social Competence. Teacher is a social creature who in his life can not be separated from the social life of society and the environment (Mulyasa 2007: 173). Therefore, teachers are required to have adequate social competence, especially in relation to education, which is not limited to learning in school, but also in the community environment. In accordance with Law Number 14 Year 2005 regarding Teachers and Lecturers Article 10 paragraph 1 , it is explained that what is meant by social competence is the ability of teachers to communicate and interact effectively and efficiently with learners, fellow teachers, parents I guardians of learners, and surrounding communities. Social competence is the ability of teachers to communicate and get along effectively with learners, fellow educators, education personnel, parents / guardians of learners, and the surrounding community. These competencies have sub competencies with the following essential indicators: a). Be able to communicate and get along effectively with learners having essential indicators: communicating effectively with learners. b). Able to communicate and get along effectively with fellow educators and education personnel. c). Able to communicate and socialize effectively with parents / guardians of learners and the surrounding community.

Professional competence is a mastery of learning materials in a broad and deep, which includes the mastery of curriculum material subjects in schools and scientific substances that overshadow the material, and mastery of the structure and methodology of science. Each sub competence has the following essential indicators: (1) Mastering the scientific substance associated with the field of study has an essential indicator: understand the teaching materials that exist in the school curriculum; understand the structures, concepts and methods of scholarship that are sheltered or coherent with teaching materials; understanding the conceptual relationship between related subjects; and apply the concepts of science in everyday life; (2) Mastering the structure and methods of science have essential indicators master the steps of research and critical study to deepen the knowledge / subject matter.

In full the teacher competence includes (a) the introduction of in-depth learners; (b) the mastery of both disciplinary content and teaching materials in the school curriculum; (c) the provision of educational learning which includes the planning and implementation of learning, evaluation of processes and learning outcomes, and follow-up for improvement and enrichment; and (d) continuous development of personality and professionalism.

From the above statement it can be said that the teaching profession is a special functional position based on the same mindset that is: (1). The recognition of the unique expert service by the government and society and the service can only be done by people who have carefully designed education , systematically and continuously specially prepared to perform certain tasks; (2) .Provision of licenses or certificates as a form of government and / or community recognition to perform services through strict screenings so that the provision of services can be done competently and promote meaningfulness for the recipient of the service; (3). Providing a decent appreciation to the expertise of the services of the community and the government so as to enable expert service providers to pursue their work and continuously improve their abilities.

\section{METHOD}

This research includes descriptive research. The place of research is carried out in all accredited VHSs in North Morowali Regency, VHS 1 Petasia, VHS 1 Mori Atas, VHS Rahmani Beteleme, VHS Lemboraya. The study was conducted for two months i.e. February 2018 until March 2018. Population and sample are 178 Vocational High School Students. Data collection used in this research 
are: documentation and questionnaire. Data analysis techniques in this study using descriptive statistical data analysis. The steps in the statistical analysis in this study are as follows: Presentation of data using Microsoft Excel 2013 software aid and SPSS (Statistical Product and Service Solution) software version
22 for Windows. Microsoft Excel 2013 software is used to present data in the form of graphs and process instrument data, which then becomes data that is ready to be processed by using SPSS software version 22. SPSS version 22 is used to process and present data on the classification of category Very High, High, Low, Very low.

Table 1. Category of Competency Rating

\begin{tabular}{lcc}
\hline No & Interval & Category \\
\hline 1. & $(\mathrm{Mi}+1,5 \mathrm{SD})>-\leq(\mathrm{Max}$ Score $)$ & Very High \\
2. & $\mathrm{Mi}>-\leq(\mathrm{Mi}+1,5 \mathrm{SD})$ & High \\
3. & $(\mathrm{Mi}-1,5 \mathrm{SD})>-\leq \mathrm{Mi}$ & Low \\
4. & $($ Min Score $) \geq-\leq(\mathrm{Mi}-1,5 \mathrm{SD})$ & Very Low \\
\hline
\end{tabular}

Table description:

Ideal Average $(\mathrm{Mi}) \quad=$ (highest score + Lowest score $) / 2$

Ideal SD $\quad=$ (highest Score-Lowest score) $/ 6$

Max Score = number of items $\mathrm{x}$ highest answer alternative score (4)

Min Score $\quad=$ number of items $\mathrm{x}$ lowest alternative answer score (1)

\section{RESULTS AND DISCUSSION}

\section{Results}

\section{Pedagogical Competencies of Vocational Teachers.}

Aspects of pedagogical competence of teachers, there are 18 items of questions divided into 5 sub indicators, namely Mastering the characteristics of learners, organizing the lesson, Utilizing the Technology in the learning that is held, Conducting the results of the assessment of learning, Doing reflective action to improve the quality of learning. The minimum score of the grain is 1 and the maximum score per item is 4 (four alternate answers). From the calculation is known that answer 178 respondents get mean score (mean) of 48.07 ; median value of 48.07 ; and the most frequent value (mode) is 48 , the data has standard deviation (std. deviation) that is 8,935 and variance 79,826 . The minimum value obtained is 28 and the maximum value is 70 , and the total score (sum) is 8556 .

To know the trends of data pedagogics competency aspects of vocational teachers VHS in North Morowali District can be done by comparing the amount of average results of research (empirical) with the average criteria set. Based on the calculation results obtained research results (empirical) of 48.07 value is greater than the average criterion of 45 . It shows that the pedagogical aspects of vocational teachers VHS teachers in North Morowali Regency as a whole is high.

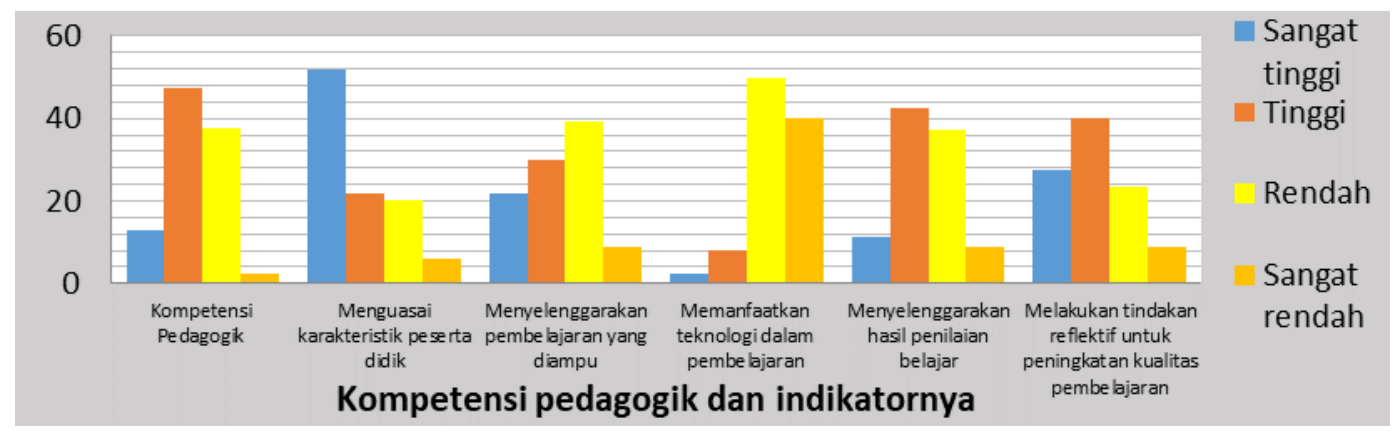

Figure 1. Histogram aspects of pedagogical competency of vocational teachers according to the Student's perception.

The result of the research can be explained that the respondent's answer (12.9\%) is very good category, respondent answer
(47.2\%) including good category, respondent answer $(37.6 \%)$ including medium category and respondent answer $(2.2 \%)$ including low / bad 
category. Teacher pedagogic competence is the ability of teachers in managing learning. Pedagogic competence of vocational teachers (productive) get a total score of 8556 and the high score set is 12816. If the calculated percentage of achievement score, then the pedagogic aspects of vocational teachers (productive) VHS in North Morowali District reached $66.76 \%$ of the highest score set with good category.

\section{Professional Vocational Teacher Competency}

VHS vocational teacher productivity in North Morowali Regency in this study refers to the rules or laws, based on the aspect of professional competence of teachers, there are 10 items of statement that is divided into $4 \mathrm{sub}$ indicators, namely Mastering the learning materials that are implemented, Linking the competence of expertise taught with other relevant aspects, Mastering up-to-date issues related to skilled competency skills, mastering theoretical competencies in theory and practice. The minimum score of the grain is 1 and the maximum score per item is 4 (four alternative answers).

Based on the results of descriptive statistical analysis it is known that answers 178 respondents get a mean score of 31.17 ; median value of 31.00 ; and the most common value (mode) is 32, The data has standard deviation (std. deviation) that is 5,291 and variance 27,994. The minimum value obtained is 17 and the maximum value is 40 , and the total score (sum) is 5548. Based on the calculation results obtained research (empirical) of 31.17 value is greater than the average criterion of 25 . It shows that the aspect of competence vocational vocational teacher professionals in North Morowali District as a whole including high / high.

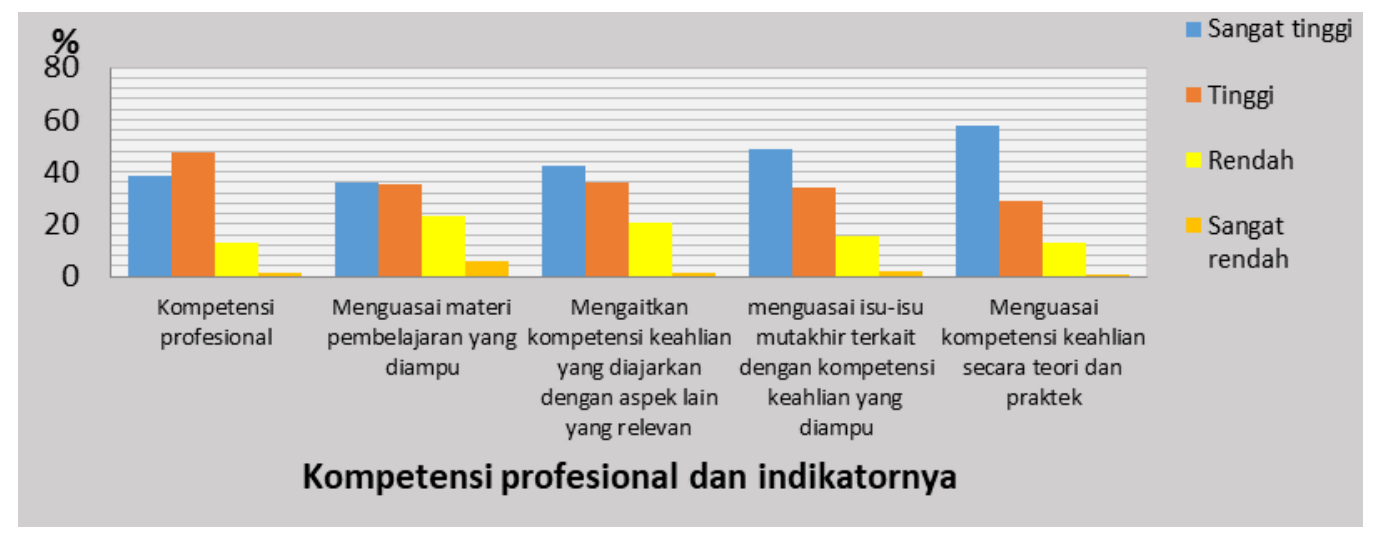

Figure 2. Professional Competency Histogram according to Student's perception

The result of the research can be explained that the respondent's answer $(38.8 \%)$ is very high / very good category, respondent answer $(47,2 \%)$ including high / good category, respondent answer $(12,9 \%)$ including medium category and answer respondents (1.1\%) including low / bad category. Based on the data category of professional competence aspects of vocational teachers VHS in North Morowali Regency included in either category. Professional competence of vocational teachers (productive) get a total score of 5548 and the high score set is 7120 . If the calculated percentage of achievement score, then the professional competence aspects of vocational teachers (productive) VHS in North Morowali District reached $77.92 \%$ of the highest score set with high category.

\section{Vocational Teacher Personality Competence}

VHS vocational teacher productivity in North Morowali Regency in this research refers to the rules or laws, based on teacher's competency aspect, there are 11 statement items that are divided into $2 \mathrm{sub}$ indicators, that is having superior personality, become role model for the participants educate. The minimum score of the grain is 1 and the maximum score per item is 4 (four alternative answers).

The results of data obtained on the aspects of teacher personality competence is measured by using 11 items of statements with a scale of 1 to 4. Based on the results of descriptive statistical analysis note that answers 178 respondents get a mean score of 34.70; median 
value of 35.00; and the most common value (mode) is 35 , the data has standard deviation (std. deviation) that is 5,830 and variance 33,984 . The minimum value obtained is 16 and the maximum value is 44 , and the total score (sum) is 6177 .
Based on the calculation results obtained research results (empirical) of 34.70 value is greater than the average criteria of 27.5. It shows that the competency aspect of VHS vocational teacher's personality in North Morowali Regency as a whole is high..

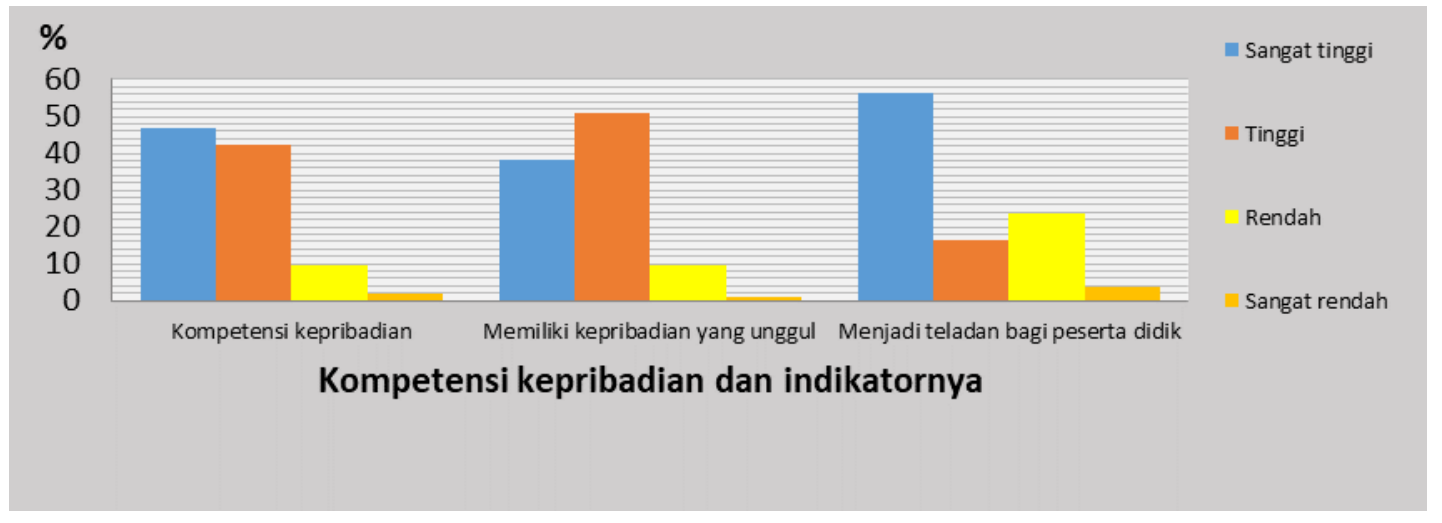

Figure 3. Competence of personality according to Student's perception

The result of this research can be explained that the respondent's answer (46.6\%) is very high / very good category, respondent answer $(42.1 \%)$ including high / good category, respondent answer $(9.6 \%)$ and respondents' answers (1.7\%) are low / bad. Vocational teacher productivity competency (earning) total score 6161 and high score determined is 7832. If calculated percentage of achievement score, hence aspect of personality competency of vocational teacher (productive) VHS in Regency North of Morowali reach $78.66 \%$ from highest score which determined with good category.

\section{Vocational Teacher Social Competencies}

VHS vocational teacher productivity formula in North Morowali Regency in this study refers to the rules or laws, based on aspects of teacher's social competence, there are 10 items statement that is divided into $4 \mathrm{sub}$ indicators, that is able to communicate well to fellow teachers, education, parents, learners, and society; be objective and non-discriminatory towards students; able to work with teams and adapt to workplace environment; able to guide students. The minimum score of the grain is 1 and the maximum score per item is 4 (four alternative answers).

From the calculation is known that answer 178 respondents get mean score (mean) of 31.93; median value of 32.00 ; and the most common value (mode) is 31 , the data has standard deviation (std. deviation) that is 5.057 and variance 25,571. The minimum value obtained is 15 and the maximum value is 40 , and the total score is 5683. To find out the data tendency of social competency aspect of vocational teacher of VHS in North Morowali Regency can be done by comparing the average of research result (empirical) with the mean of criteria determined. Based on the calculation results obtained research results (empirical) of 31.93 value is greater than the average criterion of 25. It shows that aspects of social competence of vocational teachers VHS in North Morowali Regency as a whole is high. 


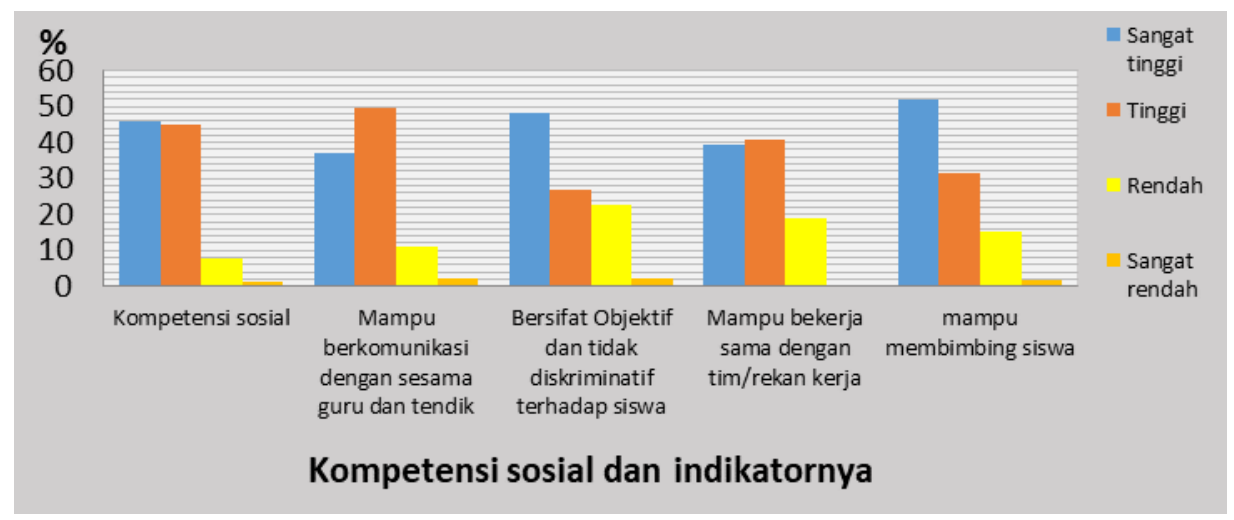

Figure 4. Social Competence according to Student's perception

The result of this research can be explained that the respondent's answer (46.1\%) is very high / very good category, respondent answer $(44.9 \%$ ) including high / good category, respondent answer $(7,9 \%)$ including medium category and respondents' answers (1.1\%) are low / bad. The social competence of vocational teachers (productive) earns a total score of 5683 and the high score set is 7120 . If the percentage of achievement score is scored, then the social competency aspects of vocational teachers (productive) VHS in North Morowali District reached $79.82 \%$ of the highest score set with good category.

\section{Discussion}

The results showed that in the aspect of pedagogic competence of productive teachers in North Morowali Regency according to the elements of leadership, productive teachers, and students as a whole is good. This is also in line with the opinion (Sudira, 2017: 131) that TVET's pedagogy is the art of teachers in leading learners as children in learning and practicing work and work effectively and efficiently. The pedagogical competence of a teacher is instrumental in guiding students to gain work competence and develop their career in a decent workplace. This is in line with the findings of Cedefop (2015: 12) "an importance conclusion is that some pedagogical dimensions are strongly associated with specific benefits for learners". The importance of pedagogical competence of teachers in the learning process is also found by Diep P.C \& Hartman (2016) which states that pedagogic competence is recommended and highly recommended for vocational teachers in the process of building TVET learning.

Professional competence is the ability to manage the learning of learners which includes mastering the learning materials that are taught, linking the competence of skills taught with other relevant aspects, mastering the latest issues related to the competence of skilled expertise, mastering the competence of expertise in theory and practice. The professional competence of vocational teachers is an important thing for a teacher to have. In accordance with opinion (Tipton, 1973, Venables, 1967, Robson, 1998a) in Robson J (2006: 14) it is said that teachers must have credibility, knowledge and expertise in accordance with their field of expertise to reflect the identity of a teacher. Professional teachers are expected to develop materials that do not yet exist in the syllabus according to the needs of learners, potential schools and teachers' ability to apply them. This is supported by Power (1999: 113) which states that "Teacher must be models of lifelong learning, constantly involved in the process of professional development and supported in their guest for higher standards of teaching".

Explanation of research result indicate that from 21 item about teacher competency aspect given to school principal, vice principal and head of study program of VHS in Regency of North Morowali, from 23 respondents assess that personality competency owned by vocational teacher se vocational as much as 78.3 $\%$ included in the category very high / very good and as much as $21.7 \%$ high category. The vocational teacher's personality competencies of the students' perceptions still require improvement to improve the quality of the educators themselves. This is in accordance with the results of the Judge's (2015: 8) research showing the result that the teacher's personality competence with regard to independence of action, work ethic, as educator, noble character, steadiness and stability based on norm, beneficial to students who have contributed positively as element forming personal 
competence. The teacher's personality competence should be well suited to Albert in Muhammad \& Jaafar (2015) that teachers should have a laudable personality, show good ethics and ethics in serving the community and as a good model for all levels of learners.

Vocational teacher social competence is an important thing for a teacher to have. This is consistent with the results of Sirk, Liivik, \& Loogma (2016: 24) research that teachers should provide support and assistance so that students can solve their personal problems, this has become one of the most important requirements and parts of teacher professionalism. Teacher social competence is the ability to communicate well to fellow teachers, educational staff, parents, learners, and the community; be objective and non-discriminatory towards students. This is supported by Mulyasa (2007: 173) that the teacher is a social creature who in his life can't be separated from the social life of society and the environment. The social competence of vocational teachers from student perceptions still requires improvement for the improvement of the quality of educators themselves. This is supported by Sudira (2016) that: "The characteristics of the working world of the XXI century are characterized by (1) collaborative critical problem solving, (2) working through cooperative networks, (3) using high-order thinking skills (critical, creative, communicative, collaborative) "from the above opinion we can conclude that the ability to communicate and socialize is needed by productive teachers.

\section{CONCLUSIONS AND SUGGESTIONS}

Pedagogic competence of vocational teachers (productive) VHS in North Morowali Regency according to the perception of students including high category with a percentage of $66.76 \%$. With indicators: mastery of the characteristics of learners with a percentage of $79.49 \%$ in the high category; the implementation of learning with a percentage of $68.68 \%$ in the high category; Utilization of technology in learning with percentage $47.47 \%$ including low category; the assessment of learning outcomes with the percentage of $64.55 \%$ in the high category; doing reflective action to improve the quality of learning with percentage $69.66 \%$ entering high category.

Professional competence of vocational teacher (productive) VHS in Regency of North
Morowali including high category equal to $77,92 \%$ with indicator: mastery of learning material which is conducted with percentage equal to $72.52 \%$ including high category; linking competence of skills taught with other relevant aspects with a percentage of $76.69 \%$ including high category; mastering the latest issues related to the skill competencies that are afforded with the percentage of $81.67 \%$ including the high category; mastery of theoretical competence in theory and practice with percentage of $83.99 \%$ including very high category.

$$
\text { Vocational teacher personality }
$$
competency (productive) VHS in North Morowali Regency including high category equal to $78.66 \%$ with indicator: having personality which is superior with percentage equal to $78.68 \%$ including high category; be an example for learners with a percentage of 79.71 including the high category.

Vocational social competence of vocational teachers (productive) VHS in North Morowali Regency including high category of $79.82 \%$ with indicators: able to communicate well to fellow teachers, education personnel, parents, learners, and the community with a percentage of $79.49 \%$ high category; be objective and non-discriminating against students with a percentage of 79.07 including the high category; able to work with team / adaptation with work environment with percentage of $79 \%$ including high category; able to guide students with a percentage of $82.02 \%$ including high categorization.

Teachers are expected to further improve the four competencies, especially on the use of technology and information that has a low category. The use of technology and information is absolutely necessary for teachers to obtain indepth information about vocational education, such as the use of technology in the implementation of learning. Vocational education that has high quality will be marked by the mastery of the competence of graduates who can work in the workplace. Mastery of competence of learners is determined by the quality of the competence of vocational teachers who teach, educate, and train students to master a particular field of expertise in accordance with the competence of expertise. 


\section{REFERENCE}

CEDEFOP. (2015). National qualification framework developments in Europe. Anniversary edition. Luxemburg: Publication Office of the European Union.

Dharma.S., Sugiyono., Mulyatiningsih.E., Sutopo., Irwanto., Palunsu.J.E., Triatmojo.P., Siswanto.R. (2013). Tantangan Guru Abad 21. Kemendikbud.

Firdausi, A., \& Barnawi. (2012). Profil Guru SMK Profesional. (M. Sandra, Ed.) (1st ed.). Yogyakarta: Ar-Ruzz Media.

Mulyasa E (2013). Uji Kompetensi dan Penilaian Kinerja Guru. PT. Remaja Rosdakarya. Bandung

Mulyasa E (2007). Menjadi Guru Profesional. Bandung. Remaja Rosdakarya

MacKenzie.J and Polvere.R (2009). TVET Glossary: Some Key Terms. Springer Vol 1-6.

Power. (1999). Play and Exploration in Children and Animal. New York: Taylor \& Francis.

Raymond A. Noe (2010). Employee Training and Development. The Ohio State University

Robson, J. (2006). Teacher Professionalism in Further and Higher Education: Challenges to Culture and Practice. Phsychology Press.

Sudira, P. (2016). TVET Abad XXI (1st ed.). Yogyakarta: UNY Press.
Sudira, P. (2017). TVET Abad XXI (2nd ed). Yogyakarta: UNY Press.

Tilak, J. B. G. (2003). Vocational Education and Training in Asia. In International Handbook Of Educational Research In The Asia-Pasific Region. SPRINGERSCIENCE+BUSINESS MEDIA, B.V.

MacKenzie, J., \& Polvere, R.-A. (2009). TVET Glossary: Some Key Terms. In R. Maclean (Ed.) (6th ed., Vol. 6). Canada: Springer.

Sirk. M , Liivik. R, \& Loogma,K. (2016). Changes in the professionality of vocational teachers as viewed through the experiences of long-serving vocational teachers in Estonia. Empirical Research in Vocational Education and Training. Sirk et al. Empirical Res Voc Ed Train (2016) 8:13

DOI 10.1186/s40461-016-0039-7. Springer Open.

Suyanto, \& Jihad, A. (2013). Menjadi Guru Profesional, Strategi Meningkatkan Kualifikasi dan Kualitas Guru di Era Global. (R. Fauzana \& R. P. Hilabi, Eds.). Jakarta: Esensi Airlangga Group. 